\begin{tabular}{|l|l|l||}
\hline \multicolumn{2}{|c|}{ PublisherInfo } \\
\hline \hline PublisherName & $:$ & BioMed Central \\
\hline \hline PublisherLocation & $:$ & London \\
\hline \hline PublisherImprintName & $:$ & BioMed Central \\
\hline \hline
\end{tabular}

\title{
IL-4 gene therapy for collagen arthritis
}

\begin{tabular}{|l|l|l||}
\hline \multicolumn{2}{|c|}{ ArticleInfo } \\
\hline \hline ArticleID & $:$ & 162 \\
\hline \hline ArticleDOI & $:$ & $10.1186 /$ ar-2000-66834 \\
\hline \hline ArticleCitationID & $:$ & 66834 \\
\hline \hline ArticleSequenceNumber & $:$ & 119 \\
\hline \hline ArticleCategory & $:$ & Paper Report \\
\hline \hline ArticleFirstPage & $:$ & 1 \\
\hline \hline ArticleLastPage & $:$ & 3 \\
\hline \hline & & RegistrationDate : 2000-8-29 \\
\hline ArticleHistory & $:$ & OnlineDate \\
\hline \hline ArticleCopyright & $:$ & Current Science Ltd2000-8-29 \\
\hline \hline ArticleGrants & $:$ & \\
\hline \hline ArticleContext & $:$ & 130753311 \\
\hline \hline
\end{tabular}




\section{Keywords}

\section{Context}

IL-4 is a regulatory cytokine which counteracts the effects of the major pro-inflammatory cytokines IL-1 and TNF-a. Levels of IL-4 are reduced in the synovium of patients with rheumatoid arthritis. Therefore, treatment to increase levels of IL-4 in such patients might be beneficial. Collagen-induced arthritis in mice resembles rheumatoid arthritis, with inflammatory synovitis producing cartilage and bone erosion. To introduce IL-4 via an adenovirus vector into mice with collagen arthritis, and assess the effect of this treatment on cartilage and bone erosion.

\section{Significant findings}

A dose-related expression of IL-4 was demonstrated in the joints of naive mice and collagenimmunized mice receiving Ad5E1mIL-4, but not in control animals. There was no significant difference in scores for arthritis or histological inflammation between treatment and control groups. However, treated mice showed less type II collagen breakdown, and no (or only mild) radiographic evidence of bone erosion, compared to control mice. Treated mice also had fewer osteoclast-like cells and downregulation of IL-17, IL-6, IL-12, osteoprotegerin ligand and cathepsin K in the synovium.

\section{Comments}

This article makes two important points. First, gene therapy with the counter-inflammatory cytokine interleukin (IL)-4 is possible in an animal model of arthritis, as has been shown previously with IL-1ra (IL-1 receptor antagonist) in mice and humans. Second, gene therapy with IL-4 appears to have a major effect in preventing cartilage and bone erosion in the mouse model, despite the absence of suppression of inflammation. 


\section{Methods}

The recombinant replication-deficient adenovirus Ad5E1mIL-4 was generated by homologous recombination after cotransfecting 293 cells with PACCMVmIL-4 and a virus-rescuing vector pAdBHG10. The empty recombinant replication-deficient adenovirus Ad5del70-3 was used as a control vector. Naive mice received an intra-articular injection of either the IL-4 expressing vector (Ad5E1mIL-4) or the control vector. Male DBA-1/BOM mice were treated with bovine type II collagen to produce collagen-induced arthritis. Just before the expected onset of arthritis, the right knee was injected with either Ad5E1mIL-4 or the control vector. At days 1, 3, 5, and 7, mice were sacrificed, the appearance of arthritis in affected joints was scored, and the knee joints isolated and processed for light microscopy. Specimens were scored for inflammatory infiltrate and loss of bone.

\section{References}

1. Lubberts E, Joosten LAB, Chabaud M, van Den Bersselaar L, Oppers B, Coenen-De Roo CJ, Richards CD, Miossec P, van Den Berg WB: IL-4 gene therapy for collagen arthritis suppresses synovial IL-17 and osteoprotegerin ligand and prevents bone erosion. J Clin Invest. 2000, 105: $1697-1710$.

This PDF file was created after publication. 